https://doi.org/10.52058/2786-4952 -2021-5(5)-123-133

Верезомська Ірина Георгіївна кандидат економічних наук, доцент кафедри готельно-ресторанного i туристичного бізнесу, Київський національний університет культури і мистецтв, вул. Свгена Коновальця, 36, Київ, 01601, тел.: (044) 285-44-03, e-mail: verez_kult@ukr.net, https://orcid.org/0000-0002-3289-3734

Каткова Тетяна Ігорівна доктор технічних наук, доцент, професор кафедри кібербезпеки та інформаційних технологій Факультет інноваційних технологій, Університет митної справи та фінансів, вул. Володимира Вернадського, 2/4, Дніпро́, 49000 тел.: (0562) 47-18-82, e-mail: takit777@gmail.com, https://orcid.org/0000-0002-1051-4262

\title{
КЛІПОВЕ МИСЛЕННЯ У КОНТЕКСТІ ОСВІТНІХ ПРАКТИК: ТРЕНДИ ГЛОБАЛІЗАЦІї
}

Анотація. Освіта поряд з будь-якою іншою сферою суспільної діяльності залежна від тенденцій розвитку соціокультурного простору. Тренди, які задають тон в цивілізаційному розвитку, прийнято називати глобалізаційними. У статті розглянуто освітні практики, де актуалізується кліпове мислення. Різноманітні варіації електронного навчання $є$ сприятливим майданчиком для фрагментарного типу сприйняття та відтворення навчальних матеріалів. Наукова розвідка передбачає порівняльний аналіз вияву кліпового мислення у двох форматах: загальному електронному навчанні - e-learning (організація навчального процесу завдяки електронним всім можливим ресурсам) та мобільному навчанні - m-learning (навчання у смартфоні). Тут ключовим фактором постає джерело походження кліповості отриманої та обробленої наукової чи навчальної інформації. Тенденції до збільшення частки використання смартфонів в освітньому кластері простежуються доволі чітко.

Вказано, що кліпове мислення за умов використання формату m-learning актуалізується не лише за змістом, а й за формою. Якщо для кластеру e-learning наявні певні обмежуючі фактори (окреме місце для роботи на ПК та прив'язаність до цього місця, стабільність INTERNET-з'єднання), то навчання у смартфоні (потужні програмні можливості нових моделей, наявність постійного мобільного INTERNET-зв'язку) суттєво підвищує можливості для короткострокової активності мислення. Наразі відбувається переорієнтація програм підготовки всіх рівнів освіти 3 урахуванням потенціалу науковотехнічного супроводу навчального процесу. Освітні практики, які продукують кліпове мислення, змінили свій статус 3 альтернативних на базові. Наразі відкритим залишається питання якості освіти, яка опирається на електронний 
peсурс. Дискусія щодо доцільності використання електронного навчання 3 кліповим мисленням в основі змінилася в бік ефективності цього формату.

Ключові слова: кліпове мислення, глобалізація, електронне навчання, mlearning, якість освіти.

Verezomska Iryna Heorhiivna Candidate of Economic Sciences, Associate Professor Department of Hotel, Restaurant and Tourism Business Kyiv National University of Culture and Arts, Evgena Konovaltsya St., 36, Kyiv, 01601, tel.: (044) 285-44-03, e-mail: verez_kult@ukr.net, https://orcid.org/0000-0002-3289-3734

Katkova Tetiana Ihorivna Doctor of Technical Sciences, Associate Professor, Professor of Cybersecurity and Information Technology Faculty of Innovative Technologies, University of Customs and Finance, (Dnipro, Ukraine), Volodymyra Vernadskoho St., 2/4, Dnipro, 49000, tel.: (0562) 47-18-82, e-mail: takit777@gmail.com, https://orcid.org/0000-0002-1051-4262

\title{
CLIP THINKING IN THE CONTEXT OF EDUCATIONAL PRACTICES: TRENDS IN GLOBALIZATION
}

\begin{abstract}
Education, along with any other sphere of social activity, depends on trends in the development of socio-cultural space. Trends which set the tone for civilizational development are commonly referred to as globalization trends. The article deals with educational practices, where clip thinking is actualized. Various variations of e-learning are a favorable platform for a fragmented type of perception and reproduction of learning materials. Scientific exploration involves a comparative analysis of the manifestation of clip thinking in two formats: general e-learning (organization of the learning process thanks to electronic all possible resources) and mobile learning - m-learning (learning in a smartphone). Here the key factor is the source of origin of the clipping of the received and processed scientific or educational information. The trends towards an increasing share of smartphone use in the educational cluster can be seen quite clearly.

It is indicated that the clique mentality when using the m-learning format is actualized not only in content, but also in form. If for e-learning cluster there are certain limiting factors (separate place to work on PC and attachment to this place, stability of INTERNET-connection), then learning in smartphone (powerful software capabilities of new models, availability of constant mobile INTERNET-connection significantly increases opportunities for short-term thinking activity. There is a reorientation of training programs at all levels of education, taking into account the potential of scientific and technological support of the educational process. Educational practices that produce clip thinking have changed their status from alternative to basic. The question of the quality of education that relies on electronic resources remains open. The debate about the appropriateness of using e-learning with clip thinking at its core has changed towards the effectiveness of this format.
\end{abstract}


Keywords: clip thinking, globalization, e-learning, m-learning, quality of education.

Постановка проблеми. Освіта завжди славилася своєю традиційністю та ідентичністю. Відтак, освітнє середовище опинилося в своєрідній аксіологічній кризі, яка порушила ціннісні елементи майже всіх суб'єктів навчального процесу. 3 одного боку, маємо освітні практики, які доводили свою ефективність протягом десятків років (а, подекуди, й століть); 3 іншого виклики часу, які унеможливлюють сам формат традиційних освітніх практик. Найяскравішим прикладом подібних процесів стала ситуація в освіті за умов поширення пандемії COVID-19. Якщо раніше дистанційний формат навчання iз фундаментальним електронним форматом розглядався як альтернативний та допоміжний, то тепер він став, по суті, безальтернативним. Крім того, сучасне суспільство переживає період укорінення сталих глобалізаційних процесів глобальна мережа INTERNET, соціальні мережі, транснаціональні утворення, різноманітні союзи та об'єднання. Всі перераховані процеси мають значний вплив на освіту, продукуючи утворення нових освітніх практик, пов'язаних передовсім 3 електронним навчанням. Одним 3 ключових складників цього навчання $\epsilon$ кліпове мислення як альтернатива традиційному системноузагальнюючому формату мислення.

Питання розвитку електронного навчання, кліпового мислення набуває важливого значення в глобальному вимірі. Підтвердженням цього $\epsilon$ зацікавленість цією проблемою 3 боку організації UNESCO. Освітній спільноті пропонується робочий (не юридичний) варіант визначення поняття «e-learning», згідно 3 яким воно визначається як організація навчального процесу за допомогою технічних засобів та інформаційних мереж [1].

Аналіз останніх досліджень і публікацій. Проблемами впровадження та перспектив кліпового мислення в освітній галузі займаються як вітчизняні, так і закордонні науковці. Різниця змісту публікацій полягає у фокусі досліджень, оскільки західне суспільство значно швидше реагує на виклики часу в освіті і застосовує нові методики в навчальному процесі, які базуються на електронному навчанні.

Якщо провести аналіз наукових публікацій по тематиці кліпового мислення, то в західних джерелах загальне розуміння кліповості набуло поширення на початку XXI століття. Останні роки дослідники займалися питаннями практичного застосування електронного навчання та його результатів. Вітчизняні дослідники наразі не можуть проводити дослідження ефективності освіти, оскільки масово електронне навчання було впроваджене лише після початку пандемії COVID-19. Тому результати освітніх практик електронного навчання в Україні та відповідно наукові роботи з оцінками та перспективами подібного формату навчання очікуємо за кілька найближчих років.

Дослідження ефективності формату e-learning провели К. Basak, M. Wotto \& 
P. Bélanger. Особливості застосування e-learning та m-learning в українському освітньому просторі досліджують М. Ведмедєв, Г. Гич, Т. Ярхо, І. Книш, С. Соболєва.

Психолого-педагогічний аспект кліпового мислення в освітній сфері розкривають колективи дослідників: О. Корнута, Т. Прухоровська і Н. Потьомкіна; Я. Чаплак і I. Зварич.

Мета статті - дослідження особливостей використання формату e-learning та m-learning в освітніх практиках та відповідне формування кліпового мислення у здобувачів освіти усіх рівнів.

Виклад основного матеріалу. Електронне навчання наразі займає домінуючу роль в освітньому процесі. Розуміємо, що такий стан справ $\epsilon$ ситуативним, оскільки викликаний необхідністю застосування дистанційного навчання внаслідок пандемії COVID-19. Однак, освітнє середовище перебуває в умовах аксіологічної невизначеності. Неспроможність дотримуватися традиційних канонів викладання та навчання болісно впливає на всіх суб'єктів навчального процесу. Тим паче, освіта завжди славилася методологічною консервативністю.

Зазвичай, перетворення в освітньому кластері відбуваються поступово, 3 виваженістю висновків та глибоким аналізом ефективності. Саме так, протягом кількох років, впроваджувалися елементи електронного навчання. Незважаючи на те, що в буденно-практичному вимірі учні та студенти використовували технічні пристрої (комп'ютери, смартфони тощо) дуже активно, в освітніх практиках цей процес вбудовувався без форсування.

Для здобувачів освіти технічні елементи використовувалися в якості допоміжного фактору при формуванні знань, умінь і навичок. Щодо аспекту сприйняття та відтворення навчального матеріалу, то використання системного і критичного мислення залишалося пріоритетним в роботі педагога. Однак, глобалізаційні перетворення сучасного соціокультурного простору змінюють освітні традиції.

Передовсім, варто визначити наскільки освітній кластер інтегрований до глобалізаційних процесів сучасності. Можна стверджувати, що завдяки новітнім технологіям глобалізація полегшує доступ до освітніх послуг і сприяє обміну найновішими знаннями по всьому світу. Онлайн-заняття, наукові розвідки та академічні комунікації у школах та університетах $є$ доказом того, що освіта займає свою нішу в глобалізаційних та технологічних трендах нинішньої цивілізації [2].

Однак, порушується питання про нерівномірність розвитку технологій в окремих спільнотах (національних, регіональних чи класових). Відповідно, присутній дисбаланс в глобальному вимірі щодо доступності та поширеності електронного навчання та кліпової культури. Відтак, кожна спільнота визначає рівень інформатизації та технологізації освіти. Від цього залежить активність впровадження електронного формату навчання та формування кліпового мислення у здобувачів освіти різних рівнів. 
Зосереджуючись на ефективності електронного навчання, маємо констатувати його успішність і затребуваність в якості форми (засобу), а не змісту (мети). Кліпове мислення, в свою чергу, має стати ефективним методом в освітніх практиках, а не їхнім результатом.

Наразі крім формату e-learning пропонується визначення m-learning, яке передбачає електронне навчання 3 використанням смартфону [3]. Оскільки смартфон відіграє все більшу роль в якості невід'ємного елементу повсякденного життя, зрозуміло, що й частка його використання в навчальному процесі. Якщо розглядати смартфон як джерело інформаційного навчального контенту, то можна сміливо дійти висновку про те, що такий атрибут є найбільш сприятливим для утвердження кліпового мислення.

3 початку 2010-х років простежувалась певна напруженість, а, подекуди, й конфліктність всередині освітнього простору. 3 одного боку - традиційність освітніх методик зі своєю сталою методологією інформативного забезпечення навчального процесу, а 3 іншого - науково-технологічний процес, який забезпечував доступ до інформації, водночас, вносячи певний дисбаланс на мисленнєвому рівні.

Учні та студенти почали переносити захопленість гаджетами 3 побутового рівня до навчального. Виникла неузгодженість між можливостями та ризиками, яке несе інформатизація освітніх практик. У навчальному процесі негативні прояви мають свої особливості (рис. 1).

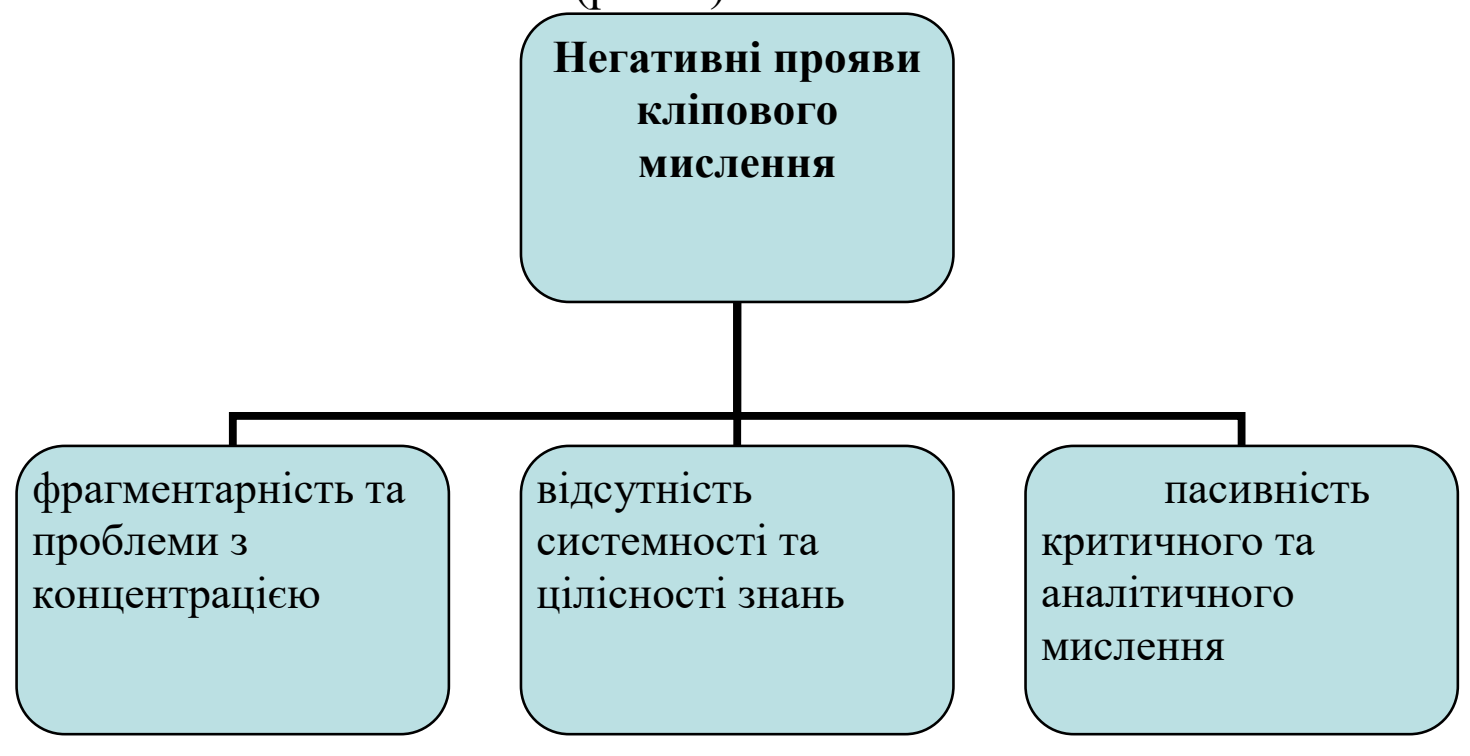

Pис. 1 Характеристика негативних проявів кліпового мислення Джерело: авторська розробка

Розглянемо детальніше ці ризики і спробуємо вияснити чи несуть вони реальну загрозу для якості освіти. Стосовно фрагментарності у психологів існують протилежні точки зору. Якщо ж мова йде про педагогічний кластер, то тут недоліки кліпового мислення перетворюються на переваги за умови введення відповідних навчально-методичних компонентів. Виклад матеріалу 3 
обов'язковими дублюючими та закріплюючими складниками забезпечать подвійний позитивний навчальний ефект. Нові форми викладу матеріалу і контролю знань 3 урахуванням електронних технологій поряд 3 педагогічною майстерністю забезпечать концентрацію уваги. Цілісність сприйняття актуалізується мотиваційними константами. Критичність мислення застосовуються до будь-якої системи отримання інформації, тому тут скоріше питання про формування індивідуальних якостей системності конкретного учня чи студента, а не проблема організації навчального процесу.

Фрагментарність кліпового мислення забезпечує високу швидкість як передачі інформації, так і перемикання iі елементів. При цьому швидкість отримання і сприйняття фактично виключає можливість вловити зв'язки між ними. Це призводить до втрати цілісності змісту i орієнтуванні на рефлексивному засвоєнню. Забезпечити формування у здобувачів освіти розуміння причинно-наслідкових зв’язків покликані навчально-методичні практики: наочність, візуалізація, структурування [4].

Стосовно позитивних ефектів кліпового мислення, то вони мають декілька ключових моментів: інформативний, комунікативний, організаційний. Таким чином, отримуємо декілька чинників, які вказують на те, що в освітньому кластері кліпове мислення має перспективи для подальшого розвитку. Поперше, обсяг інформації, яку отримує здобувач освіти завдяки blip-формату значно переважає традиційні шляхи (читання тексту підручника чи прослуховування лекцій). По-друге, значно спрощуються шляхи отримання інформації (доступ до INTERNETy дозволяє в будь-який час і в будь-якому місці отримати необхідний навчальний контент). Відтак, при організації навчального процесу з врахуванням особливостей e-learning, можна досягати поставлених цілей.

Дещо проблематичнішою у плані якості освітнього процесу є модель mlearning. Використання смартфону може спровокувати комбінування активності, коли учень чи студент відволікається на сторонню активність, яка не блокується та не фільтрується в процесі навчання. Дзвінок, повідомлення в месенджерах, рекламні банери - все це може нести не лише відволікаючу місію. Річ у тім, що використання смартфону є менш контрольованим з боку педагога і несе значно більше ризиків для формування вказаних негативних моментів фрагментарного мислення.

Ми згрупували ключові позитивні ефекти кліпового мислення, які мають глобальний характер (рис. 2). 


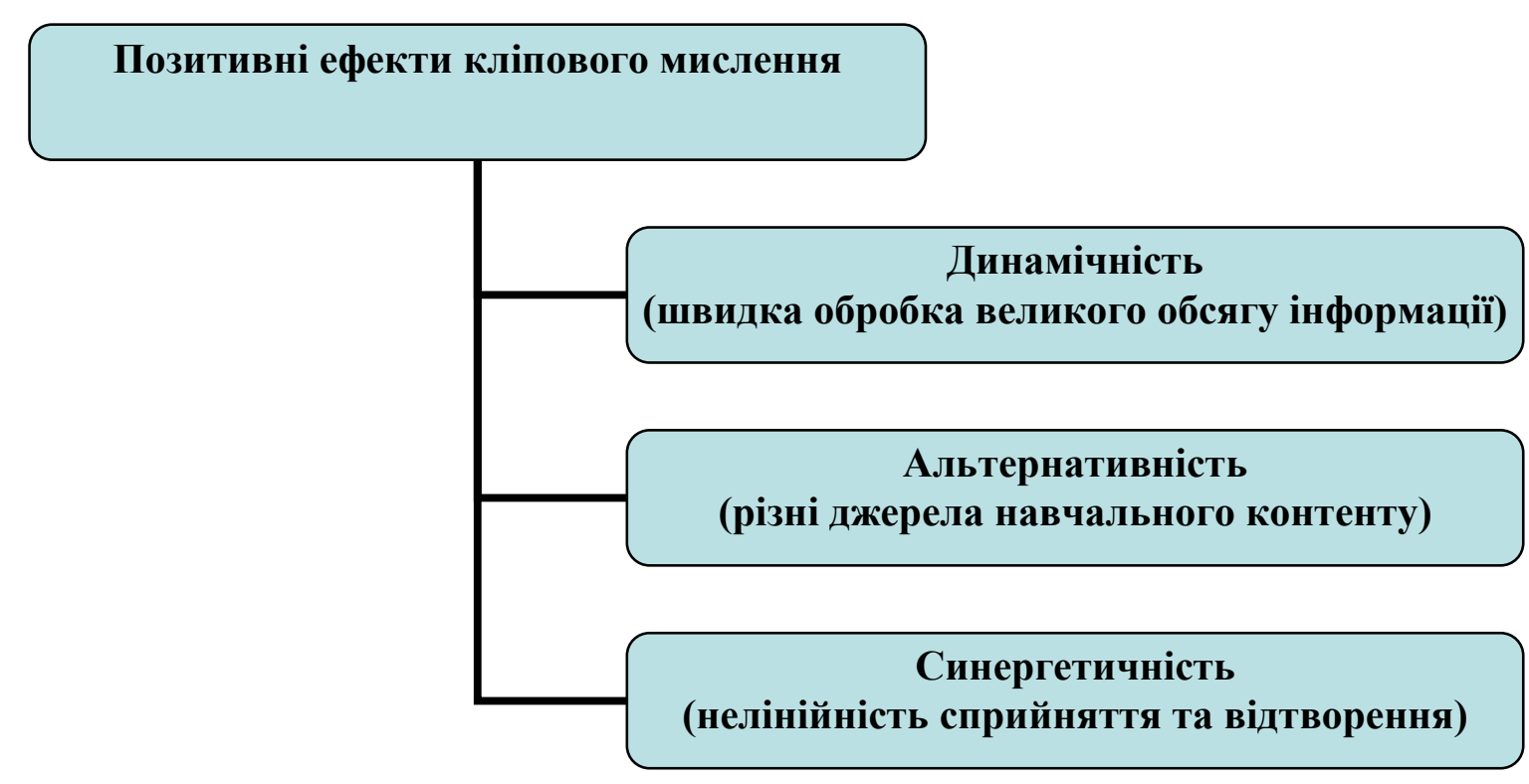

Puc. 2. Ключові позитивні ефекти кліпового мислення Джерело: авторська розробка

Досліджуючи ключові проблеми кліпового мислення в освіті, М. Ведмедєв зазначає, що «центром тяжіння, навколо якого обертається вся сукупність різноманітних обставин, часто стає текст. Мотиви його генерації, принципи композиції, особливості функціонування в медійному середовищі i, нарешті, вплив на споживача - це ті проблеми, які сьогодні з усією гостротою постали перед фахівцями» [5]. Справді, проблема «тексту» у цьому випадку є не навчально-практичною, а постає глобальним питанням універсальної лінгвістичної комунікації.

Зазначається, що поширення візуальної інформації сприятиме формуванню так званого комп'ютерного гіпертексту, особливістю якого стане активна взаємодія різних семіотичних систем. Такий стан речей підтверджує думку про кризу словесного та письмового тексту. Традиційні тексти змінюються креолізованими відповідниками, які одночасно функціонують на вербальному та невербальному рівні [6]. Подібна нелінійність стала проявом ще одного глобалізаційного тренду сучасності - синергетичної методології та міждисциплінарного наукового дискурсу.

Одним 3 простих i дієвих методів зменшення негативного впливу кліповості вважається читання художніх творів. Читання $\epsilon$ ефективним способом концентрації уваги та розвитку творчого потенціалу. Пошук чи вибір твору за власними вподобаннями дещо схожий на вибір тематики електронних ресурсів. Відтак, учень чи студент отримує альтернативу у вигляді актуалізації логічних та творчих складників [7]. Якщо ж підсумувати цей аспект у глобальному вимірі, то отримуємо ще один з поширених трендів сучасності альтернативність вибору джерела інформації, шляхів отримання навчального контенту та способи його осмислення.

Візуалізація постає трендом в сучасному розумінні ефективності подання 
інформації. Комунікація відіграє таку ж важливу роль як i сама інформативність. Ескалація зображення відповідає запитам сучасних учнів та студентів, повністю задовольняючи їхні потреби в сприйнятті інформації. Виникає нова перспектива створення інтернаціональної мови, якою може потенційно стати мова візуалізації, яка має декілька ключових переваг: сприяє взаємодії між людьми, долає стереотипи літературної чи фахової мови, сприяє нелінійній, відкритій комунікації [8].

Швидкоплинність та змінність інформативного потоку підводить людську свідомість до стану біфуркації, яка характеризується нестабільністю [9]. Переорієнтація цивілізаційного розвитку на інформаційну модель призвела до потреби формування нової освіти - здатної забезпечити навчання майбутніх поколінь.

Зрештою, кліпове мислення, електронне навчання - це все явища, які $є$ засобами для досягнення освітніх цілей. Якщо вони продемонструють ефективність в аспекті якості освіти, то стануть фундаментальними освітніми практиками, якщо ж буде простежуватися їхня неефективність, то такі методи стануть лише тимчасовою відповіддю на виклики часу.

При цьому, альтернативність породжує ще одну небезпеку, яка потенційно матиме глобальні наслідки. Мова йде про кліпову хаотичність, як результат специфіки інформаційних потоків (різна інтенсивність подачі, конкуренція серед виробників контенту, маніпуляції зі змістом і формою тощо) [10]. Існують ризики інформаційних атак та маніпуляції свідомості, що для освітнього середовища $є$ неприйнятним. Відсутність контролю над інформацією в освітньому середовищі загрожує руйнації його гуманістичних основ.

Особливістю сучасної кліпової культури $є$ плинність інформаційного потоку. Це цілком корелюється з динамічністю, яка характерна для сучасної світоглядної картини світу. Увага учня чи студента миттєво переорієнтовується як у фізіологічному, так і в психологічному аспектах. У якості ключового фактору індивідуального сприйняття інтуїція змінює аналіз.

Безглуздо заперечувати вплив високих технологій на зміни в мисленні та свідомості. Візуальна-орієнтованість стає не просто трендом сучасності, а невід'ємним складником психофізіологічного портрету свідомості людини. Динамічність мислення повністю відповідає вимогам часу в освітньому кластері. Освіта наразі не має часу на тривалу обробку інформації і не може довго чекати результатів навчання, оскільки вони дуже швидко втрачають свою актуальність [11]. Блискавичне сприйняття і швидка реакція дають не просто гарний результат, а, передовсім, забезпечують його вчасність і доречність. Сьогодні традиційна, фундаментальна освіта (навіть елітного рівня) не спроможна конкурувати на ринку. Саме тому пропозиції підвищення кваліфікації $є$ більш затребуваними ніж традиційні форми навчання для фахівців.

Ще одним моментом, на який варто наголосити є відносність проблеми витрати часу на інформаційні потоки. Однак, тут варто зазначити, що полегшення доступу та отримання інформації позбавляє пошукача рутинної 
роботи. Відтак, вивільняється багато вільного часу, який спрямовується на пошук вже не навчальної інформації.

Важливою методичною настановою $\epsilon$ не протиставлення комп'ютера i викладача, налаштування ефективної взаємодії педагогічної майстерності та потенціалу інформаційно-комп'ютерних технологій [12]. У цьому випадку формула «поганий і хороший поліцейський» не актуальна. Педагог, який виявляє зацікавленість новітніми комп'ютерними технологіями, стає для учня або студента людиною зі спільними інтересами. Тому варто переорієнтувати відношення до комп’ютерних чи мобільних технологій до формату союзництва та співпраці.

Перспективами подальших досліджень кліпового мислення в контексті освітніх практик вбачаємо в розробці взаємодії трьох ключових систем, які забезпечуватимуть якість освіти:

-технологічних систем кібербезпеки, які відповідатимуть за «чистоту» навчального контенту та його відокремлення від шкідливої, антигуманної або ж просто непотрібної інформації;

- формування індивідуальних психофізичних якостей як педагога так i учня (студента) задля запобігання негативного впливу кліпового формату навчального процесу;

-навчально-методичних систем, в яких концентруватимуться освітні практики, за допомогою яких кліповий формат можна залучити поряд 3 системним та критичним мисленням при отриманні знань.

Взаємозв'язок цих компонентів забезпечуватиме необхідну якість освіти (рис. 3).

Індивідуальна психофізична стійкість

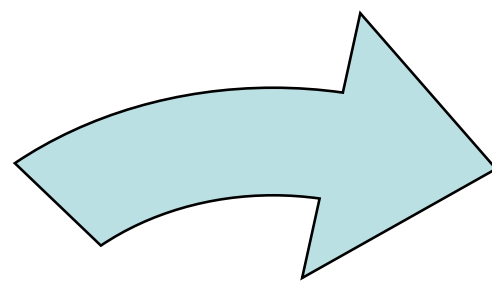

ербезпека та академічність навчального контенту

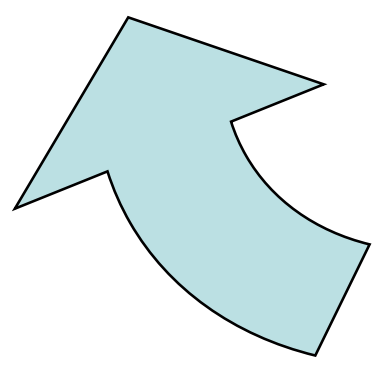

Навчально-методичні настанови форматів e-learning Ta m-learning

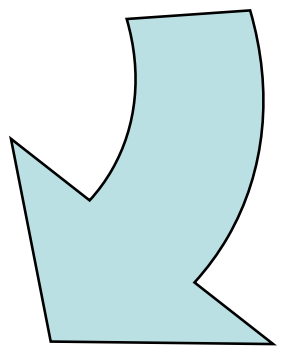

Рис 3. Взаємозв'язок ключових систем забезпечення якості освіти 
Журнал«Герспективитаінновації наукиљ

(Серія «Гедагогіка», Серія«ГТихологія», Серія«Медицина»

№5(5) 2021

\section{Джерело: авторська розробка}

Висновки. Кліпове мислення наразі посідає одне 3 ключових місць в методологічному арсеналі освітніх практик. Глобалізаційні тренди передбачають актуалізацію електронного навчання у двох поширених форматах: e-learning та m-learning. Порівнюючи показники цих двох моделей організації навчального процесу відзначимо їхню перевагу в організаційному та інформативному аспекті. При цьому, m-learning несе більші потенційні загрози для учня чи студента, оскільки слабко контролюється з боку вчителя. Проаналізувавши позитивні та негативні тенденції впровадження кліпового складника в сучасному освітньому просторі, можна констатувати його ефективність. При цьому варто регулювати фрагментарну інформацію педагогічними методиками задля уникнення втрати цілісності знань. В цілому, кліпове мислення успішно інтегрується в такі сучасні глобалізаційні виміри: інформатизацію, технологізацію, динамічність та нелінійність, синергетичний та міждисциплінарний підходи, універсальний прагматизм.

\section{Jimepamypa:}

1. UNESCO-UNEVOC Promoting learning for the world of work. 2014. URL: http://www.unevoc.unesco.org/go.php? q=e-Learning\&context (date of access: 28.11.2021)

2. Marcel M., Mkojera B. Is University Education Limited by Globalization and Technology in Developing Countries? An Observation Done during Pandemic. IntechOpen. 2021. URL: https://www.intechopen.com/chapters/73505 (date of access: 28.11.2021)

3. Kumar Basak S., Wotto M., Bélanger P. E-learning, M-learning and D-learning: Conceptual definition and comparative analysis. E-Learning and Digital Media. 2018. Vol. 15, no. 4. P. 191-216. URL: https://doi.org/10.1177/2042753018785180 (date of access: 28.11.2021).

4. Ярхо Т. Ретроспективний аналіз феномену кліпового мислення та його врахування в дидактиці сучасної математичної підготовки у технічних зво. Наукові записки Серія: Педагогічні науки, 2019. Випуск 177. С. 176-182

5. Ведмедєв М. Феномен кліпового мислення в дискусійному просторі сучаної науки. Sciences of Europe, 2021. № 70. C. 41-45

6. Kornuta O., Pryhorvska T., Potiomkina N. Clip thinking and clip perception: teaching methods aspect. Open educational e-environment of modern University, 2017. № 3. P. 75-79

7. Грицак Н. Літературна освіта молоді та проблема кліпового мислення. Science and Education a New Dimension. Pedagogy and Psychology, 2018. № 6 URL: https://doi.org/10.31174/SEND-PP2018-181VI75-05 (date of access: 28.11.2021).

8. Гич Г. «Кліпове мислення» молоді: друг чи ворог навчання. Наукові прачі Чорноморського державного університету імені Петра Могили комплексу «КиєвоМогилянська академія», 2016. Т. 269. Вип. 257. С. 38-42

9. Книш І. «Кліпове» мислення учнів (студентів) як норма і умова сучасної освіти. Світогляд - Філософія - Релігія, 2018. Вип. 13. С. 89-100

10. Чаплак Я., Зварич I. Кліпова хаотичність як засіб абсурдизації та маніпулятивна технологія. Psychological journal, 2018. № 4. С. 19-36

11. Соболєва А. Естетика кліпу в сучасному соціокультурному просторі. Екранні мистеитвва, 2018. № 22. С. 126-133

12. Іжевська О. Особливості навчання дітей з кліповим мисленням засобами IКТ. Педагогічна освіта: теорія і практика. Психологія. Педагогіка, 2019. № 31. С. 91-95 


\section{References}

1. UNESCO-UNEVOC (2014). Promoting learning for the world of work. Retrieved from http://www.unevoc.unesco.org/go.php? q=e-Learning\&context

2. Marcel, M., Mkojera, B. (2021). Is University Education Limited by Globalization and Technology in Developing Countries? An Observation Done during Pandemic. IntechOpen. Retrieved from https://www.intechopen.com/chapters/73505

3. Kumar Basak, S., Wotto, M., \& Bélanger, P. (2018). E-learning, M-learning and Dlearning: Conceptual definition and comparative analysis. E-Learning and Digital Media, 15, 191216. Retrieved from https://doi.org/10.1177/2042753018785180

4. Iarkho, T. (2019). Retrospektyvnyi analiz fenomenu klipovoho myslennia ta yoho vrakhuvannia $\mathrm{v}$ dydaktytsi suchasnoi matematychnoi pidhotovky $\mathrm{u}$ tekhnichnykh zvo [Retrospective analysis of the phenomenon of clip thinking and its consideration in the didactics of modern mathematical training in technical studies]. Naukovi zapysky Seriia: Pedahohichni nauky Scientific notes Series: Pedagogical sciences, 177, 176-182 [in Ukrainian]

5. Vedmediev, M. (2021). Fenomen klipovoho myslennia v dyskusiinomu prostori suchanoi nauky. [The phenomenon of clip thinking in the discussion space of modern science]. Sciences of Europe, 70, 41-45 [in Ukrainian]

6. Kornuta, O., Pryhorvska, T., Potiomkina, N. (2017) Clip thinking and clip perception: teaching methods aspect. Open educational e-environment of modern University, 3, 75-79 [in Ukrainian]

7. Hrytsak, N. (2018). Literaturna osvita molodi ta problema klipovoho myslennia [Literary education of youth and the problem of clip thinking] Science and Education a New Dimension. Pedagogy and Psychology, 6, URL: https://doi.org/10.31174/SEND-PP2018-181VI75-05 (date of access: 28.11.2021) [in Ukrainian]

8. Hych, H. (2016). "Klipove myslennia" molodi: druh chy voroh navchannia ["Clip thinking" of young people: a friend or foe of learning]. Naukovi pratsi Chornomorskoho derzhavnoho universytetu imeni Petra Mohyly kompleksu «Kyievo-Mohylianska akademiia»Scientific works of the Petro Mohyla Black Sea State University of the Kyiv-Mohyla Academy complex, 269, 38-42 [in Ukrainian]

9. Knysh, I. (2018). "Klipove" myslennia uchniv (studentiv) yak norma i umova suchasnoi osvity ["Clip" thinking of pupils (students) as a norm and condition of modern education]. Svitohliad - Filosofiia - Relihiia - Worldview - Philosophy - Religion, 13. 89-100 [in Ukrainian]

10. Chaplak, Ya., Zvarych, I. (2018). Klipova khaotychnist yak zasib absurdyzatsii ta manipuliatyvna tekhnolohiia [Clip chaos as a means of absurdization and manipulative technology]. Psychological journal, 4, 19-36 [in Ukrainian]

11. Sobolieva, A. (2018). Estetyka klipu u suchasnomu sotsiokulturnomu prostori. [Aesthetics of the clip in the modern sociocultural space]. Ekranni mystetstva - Screen art, 22, 126-133 [in Ukrainian]

12. Izhevska, O. (2019). Osoblyvosti navchannia ditei z klipovym myslenniam zasobamy IKT [Features of teaching children with clip thinking by ICT]. Pedahohichna osvita: teoriia $i$ praktyka. Psykholohiia. Pedahohika - Pedagogical education: theory and practice. Psychology. Pedagogy, 31, 91-95 [in Ukrainian] 